Ann. Bangladesh Agric. (2020) 24 (2) : 15-32

ISSN 1025-482X (Print)

www.doi.org/10.3329/aba.v24i2.55781

2521-5477 (Online)

\title{
THIRTY-YEAR SPATIOTEMPORAL CHANGE RECORD OF SUNDARBAN MANGROVE FOREST IN BANGLADESH
}

\author{
K. M. M. Uzzaman', M. G. Miah', H. M. Abdullah' ${ }^{1 *}$, M. R. Islam², M. S. I. Afrad ${ }^{3}$, \\ and M. J. Hossain ${ }^{1}$
}

\begin{abstract}
Accurate and realistic forest cover change assessment is essential for the conservation and management of the Sundarban mangrove forest of Bangladesh. With these views, an integrated way of the vegetation cover assessment was conducted using time-series Landsat satellite imageries of 1991, 2001, 2011, and 2021. During the last 30-year (1991-2021), variations in four land cover classes viz. healthy vegetation, unhealthy vegetation, water body, and sandbar were recorded. It showed a decreasing trend of forest vegetation and a subsequent increase of water bodies during the study period. The healthy vegetation and unhealthy vegetation decreased at 1.33 and $1.66 \%$, respectively, whereas water bodies increased $2.55 \%$ at the same time. The healthy vegetation consistently decreased over the decades, but unhealthy vegetation decreased during the 2001-2011 period. Conversion from healthy vegetation to unhealthy vegetation and unhealthy vegetation to healthy vegetation during 1991-2001 was similar. Such transform was much higher from unhealthy to healthy vegetation during 2001-2011. Transformation of healthy vegetation to unhealthy vegetation was remarkably higher during the 2011-2021 period. Further continuous change detection and classification algorithm (CCDC) showed a stable pattern over the study period without significant breakpoints. This study reveals the need for regular mangrove forest monitoring. The findings of this study can be used as a reference in the formulation and implementation of sustainable mangrove forest conservation and management.
\end{abstract}

Keywords: Sundarban, forest vegetation, change detection, sustainable management.

\section{Introduction}

Forests cover nearly one-third of the total landmass in the world but are not equally distributed (FAO, 2020). Forest are now very critical in maintaining carbon balance, biodiversity, water supply, and as a source for bio-based products (Lundback et al., 2021). Globally, forest areas are declining considerably for the last 2-3 decades (Abdullah et al., 2019; Abdullah et al., 2015; Keenan et al., 2015; Morales-Hidalgo et al., 2015). However, the mangrove forest comprising 0.7 percent of the total tropical forests in the world is the most productive for having a unique accumulation of flora and fauna (Donato et al., 2011; Islam et al.,

${ }^{1}$ GIS and Remote Sensing Lab., Department of Agroforestry and Environment, Bangabandhu Sheikh Mujibur Rahman Agricultural University, Bangladesh. ${ }^{2}$ Department of Agronomy, Bangabandhu Sheikh Mujibur Rahman Agricultural University, Bangladesh. ${ }^{3}$ Department of Agricultural Extension and Rural Development, Bangabandhu Sheikh Mujibur Rahman Agricultural University, Bangladesh. *Corresponding author: hasan.abdullah@bsmrau.edu.bd 
2005). A large extent of mangrove forest was established in Asia (42.0\%), followed by Africa and North and Central America (Giri et al., 2011). In South Asia, it occurs alongside the tidal sea brink of Bangladesh, India, Pakistan, and Sri Lanka representing about 7.0 percent of the global mangrove forests. Sundarban, the largest adjoining mangrove forest, is located on the border of Bangladesh and India. These woodlands deliver essential goods and ecosystem facilities to the coastline people and support the environment (Giri et al., 2015; Giri et al., 2011b). The major provisioning services of the Sundarban are timber, fuelwood, fish, thatching materials, honey, and waxes (Sannigrahi et al., 2019; Kibria et al., 2018; Rahman et al., 2018; Islam et al., 2017; Uddin et al., 2013). The biodiversity-rich Sundarban mangrove forest is attractive and favorable for flourishing ecotourism (Chakraborty et al., 2020; Uddin et al., 2013). Although the mangrove forests support various human activities over the years, they are lessening seriously for having many dependencies (Giri et al., 2007; Sahu et al., 2015). The losses are largely attributed to many anthropogenic activities (Romanach et al., 2018), coastal development (Feka et al., 2011), aquaculture (Hamilton, 2013), logged for timber (Palacios et al., 2017), fuelwood collection (Rasquinha and Mishra, 2021), and climate change (Alongi, 2008; Feller et al., 2017).

About half of the shoreline families hinge on straight on the Sundarban mangrove assets for their income through extracting fuelwood, fish, honey, Nipa palm (golpata) (Shah and Datta, 2010). These economic activities are threatened by the degraded ecosystem services of the forest (Uddin et al., 2013). The updated databases on the status and condition of the ecosystems are vitally important for the sustainable management of mangrove resources. Therefore, continuous supervising of the mangrove assets could be the best way to maintain those ecosystem services. Performing such tasks is very difficult from the ground or water-based surveys. Remote sensing data can provide spatiotemporal update information on mangrove status regularly. It also offers the assessment of large-scale land cover dynamics with minimum cost (Kuenzer et al., 2011). Remote sensing and GIS might perform a vital and active character in the valuation and intensive care of Sundarban mangrove timberland cover change dynamic forces (Mondal and Debnath, 2017). The remaining average resolution pictures delivered by Landsat $(30 \mathrm{~m})$ are possibly a proper instance (Abdullah et al., 2019).

Although there is numerous land-use change information, such information on inshore Bangladesh is still deficient, mainly due to the poor attribute of available distantly guess data above a diverse and dissimilar beach site. However, few studies exist on Sundarban land cover change in the shoreline zones of Bangladesh (Abdullah et al., 2019; Hasan et al., 2020). So, the detailed studies on Sundarban ground causing alteration in the seaside regions of Bangladesh using time series of satellite imagery will provide a comprehensive picture of the changes. Past research on Sundarban mangrove forest includes conservation and restoration (Romanach et al., 2018; Vyas and Sengupta, 2012); monitoring the forest cover changes (Islam et al., 2019; Kumar et al., 2021); quantification of ecosystem services (Hossain et al., 2016; Iqbal, 2020); livelihood dynamics 
of the communities (Kibria et al., 2018; Mozumder et al., 2018); degradation (Islam and Bhuiyan, 2018); species distribution (Barik et al., 2018); climate resilience of the Sundarban mangrove forest (Minar et al., 2013; Chakma et al., 2021). However, there is a definite knowledge gap regarding the updated status and distribution of healthy and unhealthy vegetation conditions of the Sundarban mangrove forest. Therefore, the researchers analyzed the time series of multispectral satellite imagery and quantified spatiotemporal patterns of the Sundarban mangrove forest cover change to achieve this goal.

\section{Materials and Methods}

\section{Study area}

Sundarban is located at the south of the Tropic of Cancer and remains amid $89^{\circ} 00^{\prime} \mathrm{E}$ and $89^{\circ} 55^{\prime} \mathrm{E}$ longitude and $21^{\circ} 30^{\prime} \mathrm{N}$ and $22^{\circ} 30^{\prime} \mathrm{N}$ latitude. The study area is the part of Sundarban, situated at the side of southwestern Bangladesh interim the Baleshwar waterway in the East and the Harinbanga stream in the west head-to-head to the Bay of Bengal (Fig. 1). The total area of the Sunderban was 15764.96 Sq. Km. (BBS, 2018). Space includes plane isles enclosed with brackish swamplands and thick plantations interrupted by an arrangement of inlets, tidal tributaries, and bays traversed by irregular loud networks. It has a rainy season environment with elevated moisture of around 80.0 percent due to the abundant inlets and the end-to-end Bay of Bengal. The region is minded to whirlwind actions and has a sumptuous past of storms striking the area and governing to damage survivors and belongings.

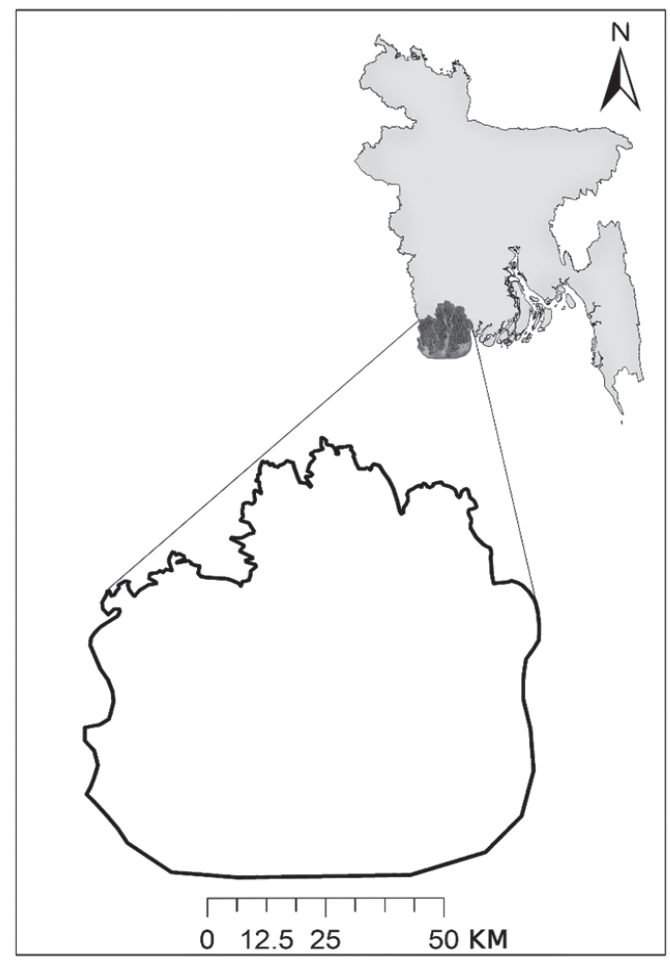

Fig. 1. Map of the study area showing its location within Bangladesh

Outside mangrove plantations, which are the leading plants, the forest has great biodiversity. It is also home to a large number of animals, both earthly and aquatic. The biodiversity includes more than 300 species of vascular plants, 250 fishes, and 300 birds, besides numerous species of phytoplankton, fungi, bacteria, zooplankton, benthic invertebrates, mollusks, reptiles, amphibians, and mammals exist (Gopal and Chauhan, 2006; Rahman et al., 2015).

\section{Data acquisition and preparation}

Time series Landsat satellite images of 1991, 2001, 2011, and 2021 were used to analyze mangrove forest cover change. All the images were taken from the United States Geological 
Survey (USGS) website (http://espa.cr.usgs). The details of the satellite imageries are illustrated in Table 1. The images are composed of Landsat Thematic Mapper (TM) and Operational Land Imager (OLI), respectively, having Path 137 and 138 and Row 45. The images were $30 \mathrm{~m}$ spatial resolution with less than 1.0 percent cloud cover. Considering the seasonal deviation in the classification output images of a similar period of each year were used. Hence, we used images available in January and February. Surface reflectance (SR) band in 1991, 2001, 2011, and 2021 along with Enhanced Vegetation Index (EVI), Normalized Difference Vegetation Index (NDVI), Soil Adjusted Vegetation Index (SAVI), Modified Soil Adjusted Vegetation Index (MSAVI) were used to comprise multiband imagery. Besides Landsat SR bands, vegetation indices were incorporated to prepare the multiband imagery. Vegetation indices (VIs) possess unique characteristics to portray the health of the vegetation. VIs are also helpful to delineate forest from other land covers so we incorporated VIs in the multiband imagery. During the multiband image creation, VIs were incorporated.
Equations of VIs are furnished below.

$\mathrm{EVI}=\mathrm{G} *((\mathrm{NIR}-\mathrm{R}) /(\mathrm{NIR}+\mathrm{C} 1 * \mathrm{R}-\mathrm{C} 2 * \mathrm{~B}+\mathrm{L}))$

$\mathrm{NDVI}=(\mathrm{NIR}-\mathrm{Red}) /(\mathrm{NIR}+\mathrm{Red})$

SAVI $=(($ NIR - Red $) /(\mathrm{NIR}+\mathrm{Red}+\mathrm{L})) \times(1+\mathrm{L})$

MSAVI $=($ NIR-Red $) /(\mathrm{NIR}+\mathrm{Red}+\mathrm{L}) *(1+\mathrm{L})$

Multiband/layer stacking was accomplished in QGIS version 3.10. After multiband/layer stacking, a custom shapefile was created using QGIS to cover the dynamic mangrove forest. Using this shapefile, all the satellite imageries were trimmed. Entire multiband pictures were stable as false-color combinations (4, 3, 2 for Landsat 4-5 and, 5, 4, 3 for Landsat 8) in QGIS. In this study, the "-9999" value was allocated to no data pixels. A comprehensive study framework has been presented in Fig. 2 .

\section{Image classification}

Classification of satellite images engages the distribution of spectral signatures for several land use and land cover (LULC) classes. Spatial-temporal LULC map aids in identifying the variations in the area of various LULC by emphasizing the trend and pattern of LULC change of a specific place. QGIS

Table 1. The attributes of Landsat imageries used

\begin{tabular}{lccccc}
\hline Satellite & Sensor & Path/Row & $\begin{array}{c}\text { Julian day of } \\
\text { accusation }\end{array}$ & Resolution & Projection \\
\hline Landsat 4-5 & TM & $137 / 045$ & 1991042 & $30 \mathrm{~m}$ & UTM/WGS 84 \\
Landsat 4-5 & TM & $138 / 045$ & 1991049 & $30 \mathrm{~m}$ & UTM/WGS 84 \\
Landsat 4-5 & TM & $137 / 045$ & 2001012 & $30 \mathrm{~m}$ & UTM/WGS 84 \\
Landsat 4-5 & TM & $138 / 045$ & 2001021 & $30 \mathrm{~m}$ & UTM/WGS 84 \\
Landsat 4-5 & TM & $137 / 045$ & 2011033 & $30 \mathrm{~m}$ & UTM/WGS 84 \\
Landsat 4-5 & TM & $138 / 045$ & 2011056 & $30 \mathrm{~m}$ & UTM/WGS 84 \\
Landsat 8 & OLI & $137 / 045$ & 2021035 & $30 \mathrm{~m}$ & UTM/WGS 84 \\
Landsat 8 & OLI & $138 / 045$ & 2021044 & $30 \mathrm{~m}$ & UTM/WGS 84 \\
\hline
\end{tabular}


Landsat images were downloaded from USGS Global Visualization Viewer (GloVis)

All the images were surface reflectance (SR) band with EVI, SAVI, MSAVI, NDVI band in the year of 1991, 2001, 2011 and 2021
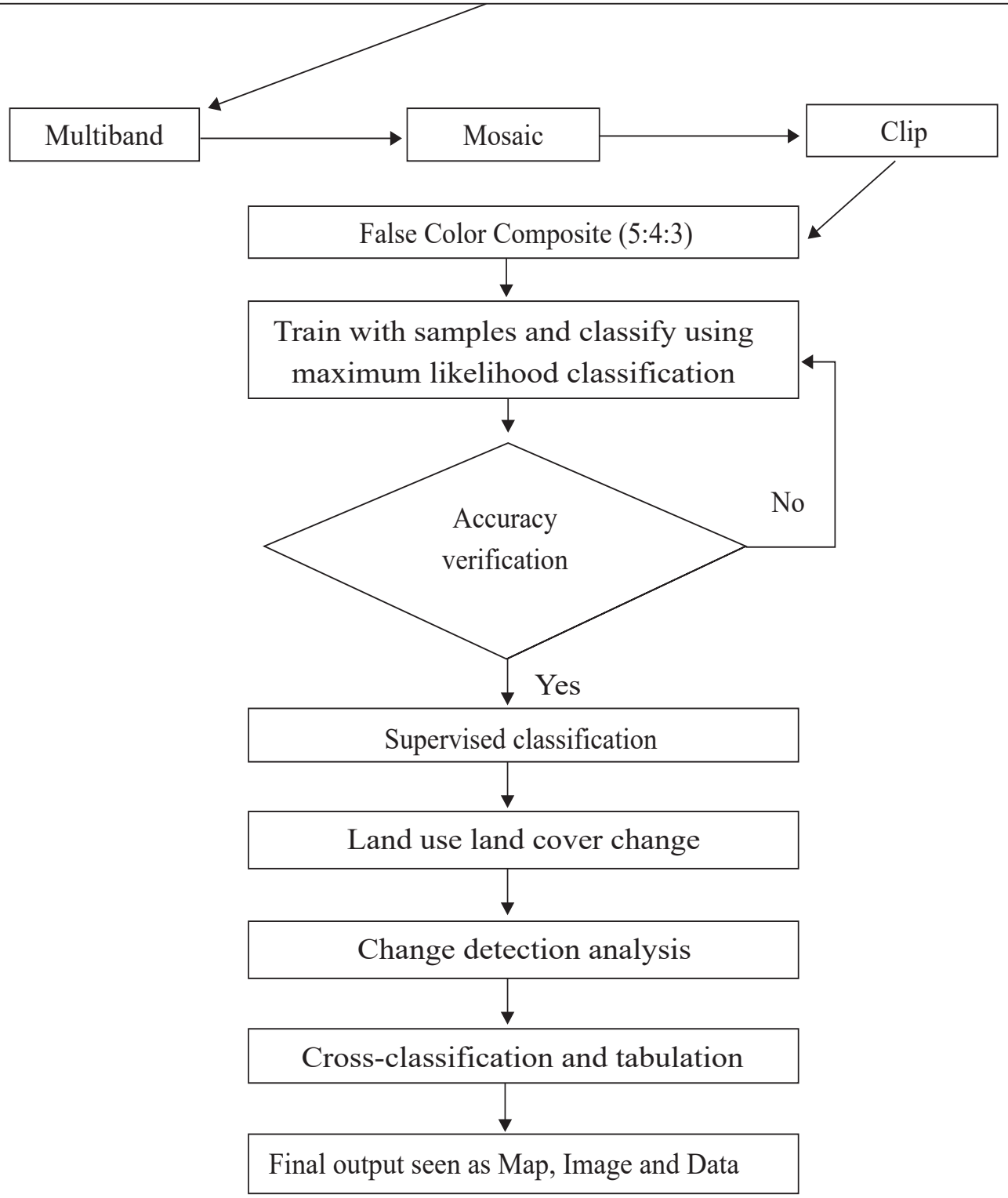

Fig. 2. The framework of the study showing steps of satellite imagery collection, preprocessing, processing, and documenting the final output. 
Table 2. Forest and other land cover grouping arrangement for this learning

\begin{tabular}{|c|c|}
\hline LULC classes & Description \\
\hline $\begin{array}{l}\text { Healthy } \\
\text { vegetation }\end{array}$ & $\begin{array}{l}\text { All type of vigorous and robust } \\
\text { mangrove forest cover }\end{array}$ \\
\hline $\begin{array}{l}\text { Unhealthy } \\
\text { vegetation }\end{array}$ & $\begin{array}{l}\text { Sparse and poorly grown } \\
\text { mangrove forest cover }\end{array}$ \\
\hline Water bodies & $\begin{array}{l}\text { Open ocean, river channels, } \\
\text { rivulets, and canals in } \\
\text { Sundarban }\end{array}$ \\
\hline Sandbar & $\begin{array}{l}\text { Sandy surface along the beach } \\
\text { in Sundarban }\end{array}$ \\
\hline
\end{tabular}

software was used and applied the maximum likelihood technique for LULC classification. A complete of 20 sample signatures for each LULC were picked up individually for every satellite image. Therefore, four LULC categories were identified i.e. healthy vegetation, unhealthy vegetation, water bodies, and sandbar. The LULC classification schematic is represented in Table 2 and Fig. 3.

\section{Accuracy assessment}

Accuracy assessment is the procedure used to quantify the reliability of a classified image in terms of the real world. The standard accuracy assessment procedure is to construct an "error matrix". Accuracy assessment essentially determines the quality of the information derived from remotely sensed data. Overall classification accuracy and kappa statistics of every single categorized spitting image are displayed in Table 3.

\section{Variation detection investigation}

Terrestrial transformation investigation was accomplished with the QGIS-SAGA module for the four intermissions: 1991-2001, 20012011, 2011-2021, and 1991-2021. This

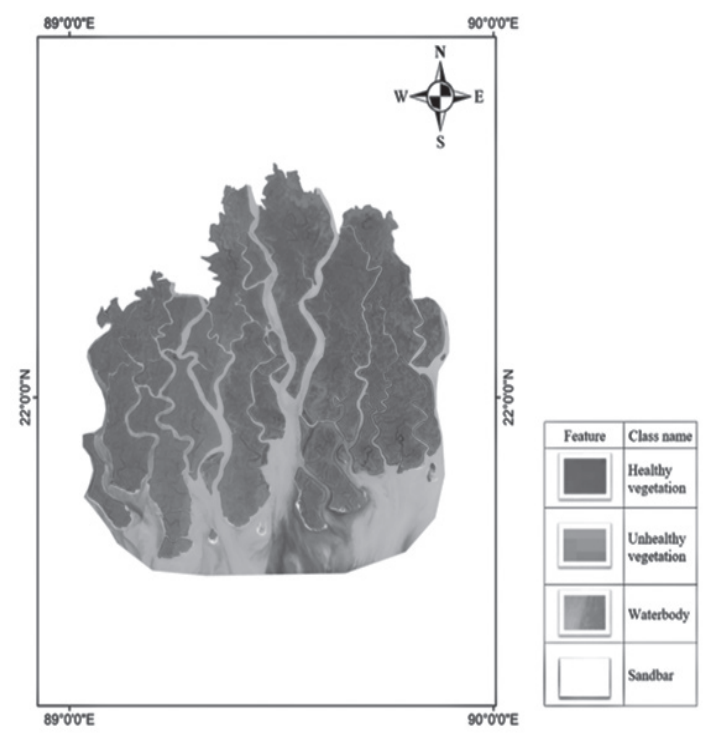

Fig. 3. False-color multiband image of 2021, with a legend showing example land cover classes.

style permitted the researchers to denote the meaningful reforms in the study part. The pixel-based cross-tabulation investigation assisted the quantification of the size of land cover change from one class to alternative and corresponding areas. It also generated a new spatial stratum holding change classes and agreeing on area values.

\section{Implementation of nonstop change finding and cataloging algorithm on Sundarban}

Continuous change detection and classification algorithm (CCDC) is gaining popularity in land use and land cover change science due to its strength in detecting land conversion. The algorithm can detect the land cover change other than noise as the noise in satellite images are ephemeral. CCDC works in two major steps for instance identify breakpoint to model stable temporal segment and finally assign class labels to new temporal segments if any. 
Table 3. Accuracy assessment of classified images

\begin{tabular}{lccc}
\hline Reference Year & Classified image & $\begin{array}{c}\text { Overall classification } \\
\text { accuracy }\end{array}$ & $\begin{array}{c}\text { Overall kappa } \\
\text { statistics }\end{array}$ \\
\hline 1991 & Landsat 4-5 TM & 0.95 & 0.94 \\
2001 & Landsat 4-5 TM & 0.94 & 0.93 \\
2011 & Landsat 4-5 TM & 0.95 & 0.94 \\
2021 & Landsat 8 OLI & 0.97 & 0.95 \\
\hline
\end{tabular}

CCDC algorithm was carried out to identify the breakpoints from archived Landsat timeseries data. Breakpoints represent changes in land use and land cover. Landsat data from 1989 to 2021 of the study sites were assimilated for the CCDC algorithm.

\section{Results and Discussion}

\section{Overall changes in Sundarban}

Notably, healthy vegetation areas consistently decreased from 1991 to 2021, with a slightly annual decrease in each decade. Unhealthy vegetation decreased about 1.67 percent from 1991 to 2021, with a much decrease (2.34\%) from 2001 to 2011 and a slower increase during the other two decades. Water bodies increased approximately 2.52 times from 1991 to 2021, by a slightly yearly growth throughout all decades. Finally, the sandbar area decreased approximately 40.31 percent from 1991 to 2021, with a rapid decline from 1991 to 2001 and 2001 to 2011 then a bit increase during 2011 to 2021. The degree of change in land cover is presented in Table 4 .

\section{Land cover changes in Sundarban}

\section{Healthy mangrove vegetation}

Healthy mangrove vegetation is represented by healthy species which absorb most of the visible (red) light that comes from the sun as electromagnetic radiation and it reflects a large portion of the near-infrared spectrum. A slow and steady decline of the healthy mangrove vegetation (dense) area was recorded during the 30-year study period (1991-2021) (Table 5). The area occupied by healthy vegetation was 399205 ha in 1991 which decreased to 395447 ha in 2001, showing a 3758 ha reduction. The healthy vegetation again slightly declined was recorded as 379 ha and 1168 ha in 2011 and 2021, respectively. The change records demonstrated that the healthy

Table 4. Frequency of variations in land cover classes from 1991 to 2021 (rate changes regarding their unique area in the particular year)

\begin{tabular}{lcccc}
\hline Land cover categories & $1991-2001(\%)$ & $2001-2011(\%)$ & $2011-2021(\%)$ & $1991-2021(\%)$ \\
\hline Healthy vegetation & -0.94 & -0.10 & -0.30 & -1.33 \\
Unhealthy vegetation & +0.29 & -2.34 & +0.40 & -1.66 \\
Water bodies & +1.75 & +0.29 & +0.46 & +2.52 \\
Sandbar & -40.31 & -6.37 & 6.23 & -40.32 \\
\hline
\end{tabular}


vegetation area constituted 61.97, 61.39, 61.33 and 61.15 percent in 1991, 2001, 2011, and 2021, respectively of the total study area

\section{Unhealthy mangrove vegetation}

The sparse and poorly grown mangrove are recorded as unhealthy mangrove vegetation. The majority of the unhealthy mangrove vegetation was situated in the northwest part of the Sundarban. The trend of changing unhealthy mangrove vegetation areas was inconsistent during the three-decadal recording periods (Table 5). It was 11280 ha in 1991 that slightly increased in 2001, covering 11313 ha. However, 265 ha unhealthy vegetation area decreased from 2001 to 2011 after that there was an increment of 44 ha unhealthy vegetation in 2021 . The analysis displays that the unhealthy mangroves constituted 1.75 , 1.76, 1.71, and 1.72 percent in 1991, 2001, 2011, and 2021, respectively. The causes of the increase and decrease of unhealthy mangrove vegetation in different decadal periods might be due to the damaging and subsequent regeneration of mangrove forests facing various degrees of cyclones.

\section{Water bodies}

The water bodies include rivers, tributaries, and open oceans adjacent to the Sundarban mangrove forest. A consistent increase of water bodies was recorded in each estimation time. It indicates that water surface area in the Sundarban forest increased for the last 30year period (Table 5). In 1991, the area under water bodies was 232779 ha, and with this, about 4084 ha area was added in 2001. The increase of water bodies was much less during the 2001 to 2010 period, recorded only 678 ha. However, it increased at a higher rate during the 2010-2021 period, and that was 1093 ha. The percent areas occupied by water bodies were $36.14,36.77,36.88$, and 37.5 in 1991 , 2001, 2011, and 2021, respectively.

\section{Sandbar}

The sandbar evolves and sustains due to dynamic accretion and erosion in Sundarban. An inconsistent change in the sandbar was observed during the recording periods (Table 5). In 1991, the area under the sandbar was 898 ha which decreased to 539 ha, indicating a net loss of 359 ha during 1991-2001. For the next ten years, the sandbar area decreased only 35 ha, but it slightly increased during the 2010-2021 period, which was recorded 32 ha. In 1991, sandbar occupied 0.14 percent of the total study area, but after changing, it constituted $0.084,0.078$, and 0.083 percent in 2001, 2010 , and 2021, respectively. The decrease and increase in sandbar area are related to the trend of water bodies in the area.

Table 5. Brief land cover classification data during 1991-2021

\begin{tabular}{lcccccccc}
\hline \multirow{2}{*}{ Land cover categories } & \multicolumn{2}{c}{1991} & \multicolumn{2}{c}{2001} & \multicolumn{2}{c}{2011} & \multicolumn{2}{c}{2021} \\
\cline { 2 - 8 } & Area (ha) & $(\%)$ & Area (ha) & $(\%)$ & Area (ha) & $(\%)$ & Area (ha) & $(\%)$ \\
\hline Healthy vegetation & 399205 & 61.97 & 395447 & 61.38 & 395068 & 61.33 & 393900 & 61.15 \\
Unhealthy vegetation & 11280 & 1.75 & 11313 & 1.76 & 11048 & 1.71 & 11092 & 1.72 \\
Water bodies & 232779 & 36.14 & 236863 & 36.78 & 237541 & 36.88 & 238634 & 37.05 \\
Sandbar & 898 & 0.14 & 539 & 0.08 & 504 & 0.08 & 536 & 0.08 \\
Total & 644161 & - & 644161 & - & 644161 & - & 644161 & - \\
\hline
\end{tabular}



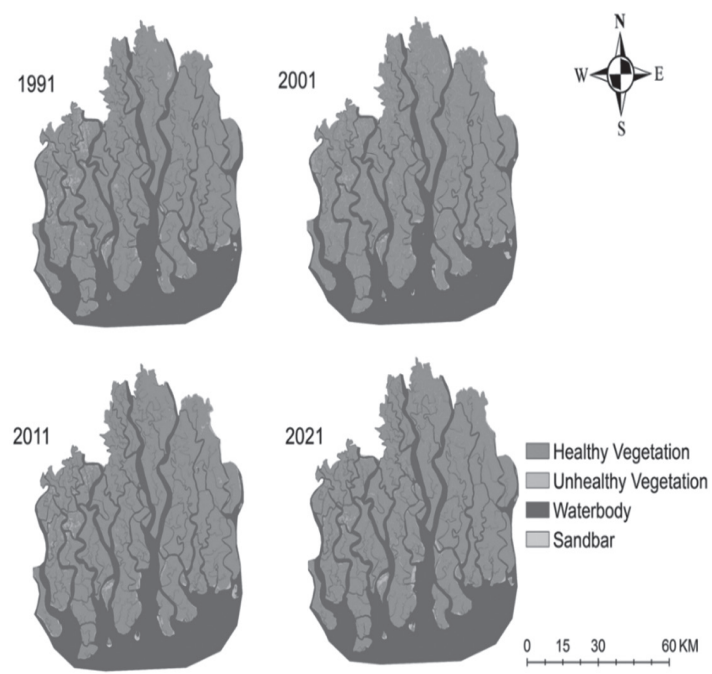

Fig. 4. Decadal land use land cover and the transformation in Sundarban over time (1991-2021)

\section{Decadal changes in Sundarban forest}

Remarkably, healthy vegetation areas consistently decreased from 1991 to 2021, with a slightly annual decrease in each decade. Unhealthy vegetation declined 1.67 percent from 1991 to 2021, with a much decrease (2.34\%) from 2001 to 2011 and a slower increase during the other two decades. Water bodies increased approximately 2.52 times from 1991 to 2021, by a slightly yearly growth throughout all decades. The sandbar area decreased approximately 40.31 percent from 1991 to 2021, with a rapid decline from 1991 to 2001 and 2001 to 2011 , then a bit increase during 2011 to 2021. The degree of change in land cover is presented in Table 4.

\section{Change detection in mangrove forest}

Alteration mold for Sundarban from 1991 to 2001,2001 to 2011,2011 to 2021 , and 1991 to 2021 for all the LULC are displayed in Table 5-8, respectively. The worth from left to right denotes deviations in the actual space of a class, and the figures from highest to lowest symbolize accompaniments to the foundation area of that class. The percent of the total area is existing in the parenthesis. For instance, in 1991, vigorous plant zones symbolized 393900ha (61.15\%) of the entire terrestrial space (Table 5). Nevertheless, in $2001,4477.73 \mathrm{ha}(0.70 \%)$ of in the beginning developed land was reclassified as unhealthy foliage, even though an extra 4733.69 ha $(0.73 \%)$ was reclassified from poorly vegetation to well vegetation; consequently, 389745.1 ha $(60.50 \%)$ of strong vegetation land keep on from 1991 to 2001. These Tables depict a larger vision of class-by-class modifications over the period.

\section{Changes from 1991 to 2001}

During the $1989-2001$ period, $60.50 \%$ of the healthy vegetation was retained in 2001, and the remaining $0.89 \%$ was converted into other land use categories (Table 6). The majority of the converted area was unhealthy vegetation $(0.70 \%)$, followed by water bodies $(0.15 \%)$ and sandbar $(0.03 \%)$. During this period, less than one-fourth of the unhealthy vegetation was retained, but a remarkable conversion took place from unhealthy vegetation to healthy vegetation $(0.73 \%)$ and water bodies $(0.50 \%)$. Most of the water bodies were unchanged, and the remaining area was altered into healthy or unhealthy vegetation. Notably, sandbar area significantly transformed to water bodies $(0.04 \%)$ and other land use categories.

\section{Changes from 2001 to 2011}

During the 2001-2011 period, most healthy vegetation was retained as the same land-use category (Table 7). About one percent (0.99\%) of healthy vegetation was transformed to other land-use categories, where transformation 
Table 6. Cross-tabulation of land transformation due to land use and land cover changes in Sundarban from 1991 to 2001

\begin{tabular}{|c|c|c|c|c|c|}
\hline \multirow[b]{2}{*}{2001} & \multicolumn{4}{|c|}{1991 Area (ha) } & \multirow[b]{2}{*}{ Total (1991) } \\
\hline & $\begin{array}{c}\text { Healthy } \\
\text { vegetation }\end{array}$ & $\begin{array}{l}\text { Unhealthy } \\
\text { vegetation }\end{array}$ & Water bodies & Sandbar & \\
\hline $\begin{array}{l}\text { Healthy } \\
\text { vegetation }\end{array}$ & $\begin{array}{l}389745 \\
(60.50)\end{array}$ & $\begin{array}{c}4478 \\
(0.70)\end{array}$ & $\begin{array}{c}998 \\
(0.15)\end{array}$ & $\begin{array}{c}225 \\
(0.03)\end{array}$ & $\begin{array}{l}395447 \\
(61.39)\end{array}$ \\
\hline $\begin{array}{l}\text { Unhealthy } \\
\text { vegetation }\end{array}$ & $\begin{array}{c}4734 \\
(0.73)\end{array}$ & $\begin{array}{c}3036 \\
(0.47)\end{array}$ & $\begin{array}{c}3204 \\
(0.50)\end{array}$ & $\begin{array}{c}340 \\
(0.05)\end{array}$ & $\begin{array}{l}11313 \\
(1.76)\end{array}$ \\
\hline Water bodies & $\begin{array}{c}4674 \\
(0.72)\end{array}$ & $\begin{array}{c}3685 \\
(0.57)\end{array}$ & $228333(35.45)$ & $\begin{array}{c}171 \\
(0.03)\end{array}$ & $\begin{array}{l}236863 \\
(36.77)\end{array}$ \\
\hline Sandbar & $\begin{array}{l}51.93 \\
(0.01)\end{array}$ & $\begin{array}{c}81 \\
(0.01)\end{array}$ & $\begin{array}{c}244 \\
(0.04)\end{array}$ & $\begin{array}{c}161 \\
(0.02)\end{array}$ & $\begin{array}{c}539 \\
(0.08)\end{array}$ \\
\hline Total (2001) & $\begin{array}{l}399205 \\
(61.97) \\
\end{array}$ & $\begin{array}{l}11280 \\
(1.75) \\
\end{array}$ & $232779(36.14)$ & $\begin{array}{c}898 \\
(0.14) \\
\end{array}$ & $644161(100)$ \\
\hline
\end{tabular}

Figures in parenthesis indicate the percent of the total area.

Table 7. Cross-tabulation of land conversation owing to land use and land cover differences in Sundarban from 2001 to 2011

\begin{tabular}{|c|c|c|c|c|c|}
\hline \multirow[b]{2}{*}{2011} & \multicolumn{4}{|c|}{2001 Area (ha) } & \multirow[b]{2}{*}{ Total (2001) } \\
\hline & Healthy vegetation & $\begin{array}{l}\text { Unhealthy } \\
\text { vegetation }\end{array}$ & Waterbody & Sandbar & \\
\hline $\begin{array}{l}\text { Healthy } \\
\text { vegetation }\end{array}$ & $\begin{array}{c}3887467 \\
(60\end{array}$ & $\begin{array}{c}2571 \\
(0.40)\end{array}$ & $\begin{array}{l}3775 \\
(0.59)\end{array}$ & $\begin{array}{c}31 \\
(0.01)\end{array}$ & $\begin{array}{l}395124 \\
(61.34)\end{array}$ \\
\hline $\begin{array}{l}\text { Unhealthy } \\
\text { vegetation }\end{array}$ & $\begin{array}{c}5388 \\
(0.84)\end{array}$ & $\begin{array}{c}2040 \\
(0.32)\end{array}$ & $\begin{array}{l}3591 \\
(0.55)\end{array}$ & $\begin{array}{c}30 \\
(0.01)\end{array}$ & $11048(1.72)$ \\
\hline Waterbody & $\begin{array}{c}1293 \\
(0.20)\end{array}$ & $\begin{array}{c}6622.65 \\
(1.03)\end{array}$ & $229382(35.61)$ & $\begin{array}{c}187 \\
(0.02)\end{array}$ & $\begin{array}{l}237485 \\
(36.86)\end{array}$ \\
\hline Sandbar & $\begin{array}{c}19 \\
(0.01)\end{array}$ & $\begin{array}{c}80 \\
(0.01)\end{array}$ & $\begin{array}{c}115 \\
(0.02)\end{array}$ & $\begin{array}{c}290 \\
(0.04)\end{array}$ & $\begin{array}{c}504 \\
(0.08)\end{array}$ \\
\hline Total (2011) & $\begin{array}{l}395447 \\
(61.39)\end{array}$ & $\begin{array}{l}11313 \\
(1.76)\end{array}$ & $\begin{array}{l}236863 \\
(36.77)\end{array}$ & $\begin{array}{c}539 \\
(0.08)\end{array}$ & $644161(100)$ \\
\hline
\end{tabular}

Figures in parenthesis indicate the percent of the total area.

to water bodies was dominant. Some healthy vegetation was also changed to unhealthy vegetation. However, conversion of unhealthy vegetation to healthy vegetation was remarkable $(0.84 \%)$, although conversion to water bodies was also recorded. Conversion of unhealthy vegetation to water bodies (1.03\%) was recorded remarkably. Exclusively significant land transformation happened in the sandbar, where closely one-fourth of land was transformed into water bodies, and consequently, the sandbar area declined.

\section{Changes from 2011 to 2021}

The majority of healthy vegetation (60.11\%) remains unchanged during the 2011-2021 
period (Table 8). The remaining $1.04 \%$ of healthy vegetation changed to unhealthy vegetation $(0.69 \%)$ and water bodies $(0.34 \%)$. Of the unhealthy vegetation, a significant change was the conversion to healthy vegetation $0.63 \%$ ), followed by water bodies. Conversion of water bodies to other land use categories was predominantly to healthy vegetation. Most of the water bodies (36.06\%) remain unchanged, and the rest was converted to healthy or unhealthy vegetation. The land exchange also occurred in the sandbar, where diligently half of the sandbar was changed to unhealthy vegetation and water bodies, but the sandbar area overblew overall.

\section{Overall changes from 1991 to 2021}

The healthy vegetation area changed to the unhealthy vegetation $(0.88 \%)$ and the most significant change occurred throughout the 1991 to 2021 study period (Fig. 5). In general, the healthy vegetation area decreased $(0.82 \%)$ and transformed to water bodies and unhealthy vegetation. Of the original unhealthy vegetation area, the most remarkable change was water bodies $(0.69 \%)$, although more water bodies and healthy vegetation areas were transformed into unhealthy vegetation. The most significant change was the transformation of water bodies to healthy vegetation $(2.00 \%)$. The land transformation existed in the sandbar, where nearly half of the original area was transformed to water bodies, but the sandbar area improved overall.

Continuous change detection and classification algorithm perspective

Continuous change detection and classification algorithms also show that the trend of a healthy forest, unhealthy forest, sandbar, and waterbody were stable. It follows only the monotonic phenological pattern (Fig. 6). Especially, no abrupt change is detected in the healthy forest in largescale which can be translated as stable mangrove vegetation.

Table 8. Cross-tabulation of land alteration due to land use and land cover changes in Sundarban from 2011 to 2021

\begin{tabular}{|c|c|c|c|c|c|}
\hline \multirow[b]{2}{*}{2021} & \multicolumn{4}{|c|}{2011 Area (ha) } & \multirow{2}{*}{$\begin{array}{l}\text { Total } 2011 \\
\quad(\%)\end{array}$} \\
\hline & $\begin{array}{c}\text { Healthy } \\
\text { vegetation }(\%)\end{array}$ & $\begin{array}{c}\text { Unhealthy } \\
\text { vegetation (\%) }\end{array}$ & $\begin{array}{c}\text { Water bodies } \\
(\%)\end{array}$ & $\begin{array}{c}\text { Sandbar } \\
(\%)\end{array}$ & \\
\hline $\begin{array}{l}\text { Healthy } \\
\text { vegetation }\end{array}$ & $\begin{array}{l}387207 \\
(60.11)\end{array}$ & $\begin{array}{c}4466 \\
(0.69)\end{array}$ & $\begin{array}{l}2225 \\
(0.34)\end{array}$ & $\begin{array}{c}2 \\
(0.01)\end{array}$ & $393900(61.15)$ \\
\hline $\begin{array}{l}\text { Unhealthy } \\
\text { vegetation }\end{array}$ & $\begin{array}{c}3791 \\
(0.59)\end{array}$ & $\begin{array}{l}4428 \\
(0.69)\end{array}$ & $\begin{array}{c}2789 \\
(0.43)\end{array}$ & $\begin{array}{c}85 \\
(0.01)\end{array}$ & $\begin{array}{l}11092 \\
(1.72)\end{array}$ \\
\hline Water bodies & $\begin{array}{c}4089 \\
(0.63)\end{array}$ & $\begin{array}{c}1895 \\
(0.29)\end{array}$ & $232311(36.06)$ & $\begin{array}{c}339 \\
(0.05)\end{array}$ & $\begin{array}{l}238637 \\
(37.02)\end{array}$ \\
\hline Sandbar & $\begin{array}{c}38 \\
(0.01)\end{array}$ & $\begin{array}{c}259 \\
(0.04)\end{array}$ & $\begin{array}{c}160 \\
(0.02)\end{array}$ & $\begin{array}{c}78 \\
(0.01)\end{array}$ & $\begin{array}{c}536 \\
(0.08)\end{array}$ \\
\hline Total 2021 & $\begin{array}{l}395124 \\
(61.34)\end{array}$ & $\begin{array}{l}11048 \\
(1.72)\end{array}$ & $\begin{array}{l}237485 \\
(36.86)\end{array}$ & $504(0.08)$ & $\begin{array}{c}644161 \\
(100)\end{array}$ \\
\hline
\end{tabular}

Figures in parenthesis indicate the percent of the total area. 


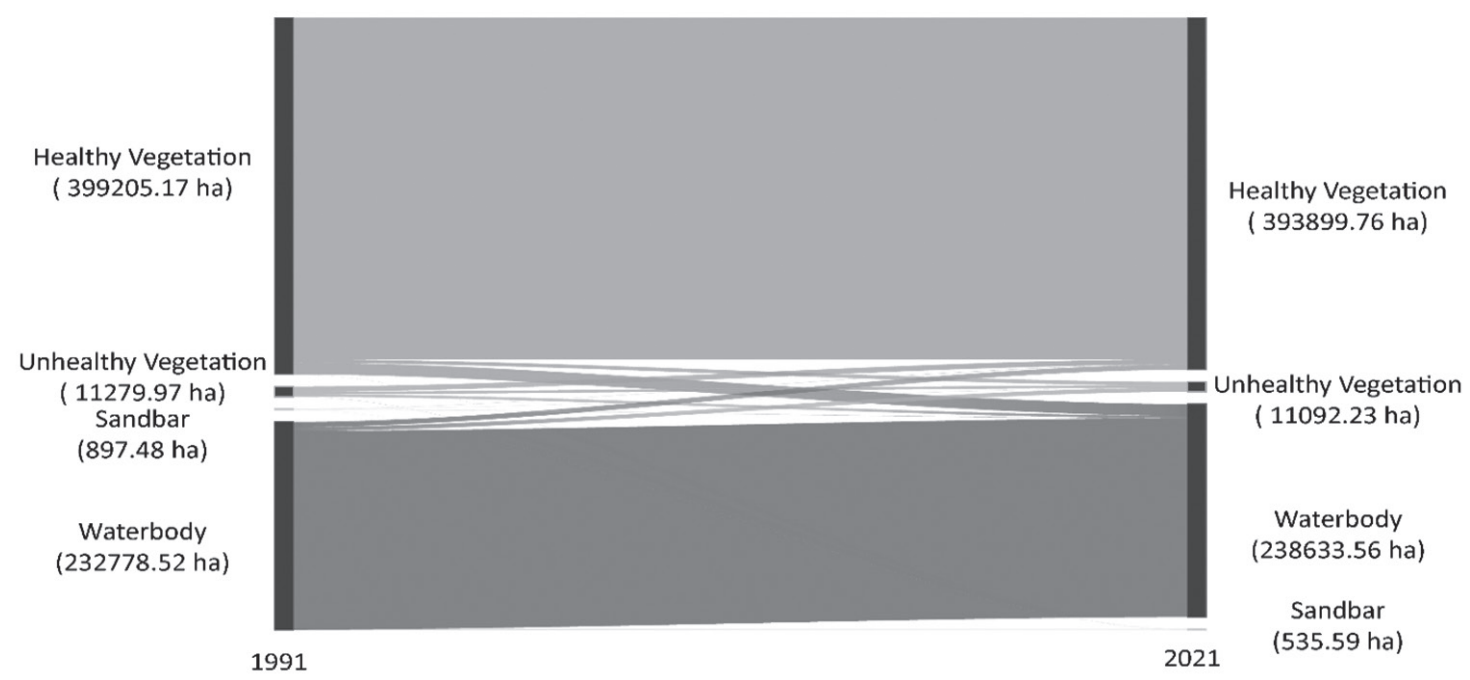

Fig. 5. Sankey diagram of land conversion in Sundarban from 1991 to 2021, showing the stable condition without a major shift in forest cover.

Insight into the change records of Sundarban Mangrove forest

Mangrove forests in many parts of the world are declining alarmingly, even more promptly than inland tropical forests. Despite having one of the top population thicknesses globally in its close neighborhood, mangrove forest areas of the Sundarban in Bangladesh have not changed significantly from the 1991s to 2021s. The multi-temporal Landsat data analysis display that the reduction in forest area from 1991 to 2021 was 1.33 percent of the 644161 ha mangrove area. This estimation includes healthy vegetation, unhealthy vegetation, water body, and sandbar classes. The healthy vegetation area decreased in different periods because of damage caused by cyclones like Sidr (November 15, 2007), Aila (May 25, 2009), and Amphan (May 20, 2020). However, some of the important initiatives, like, mangrove afforestation and management program, and several other projects like forest resources management project, integrated resource development of the Sundarban reserve forest, Sundarban biodiversity conservation project, integrated protected area co-management (IPAC) project, and Sundarban environmental and livelihoods security (SEALS) project helped a quicker regeneration of forest vegetation occurred and minimized the damaging of the mangrove forest (Rahman, 2016). Moreover, regional variations in vegetation coverage were also observed throughout the study years. Therefore, the continuing variations in climatic and global warming contribute significantly to reforming the dynamics and diversity of the Sundarban mangrove forests.

The study reveals that water bodies increased (2.52\%) from 1991 to 2021, whereas healthy vegetation, unhealthy vegetation, and sandbar areas decreased during the same period. 


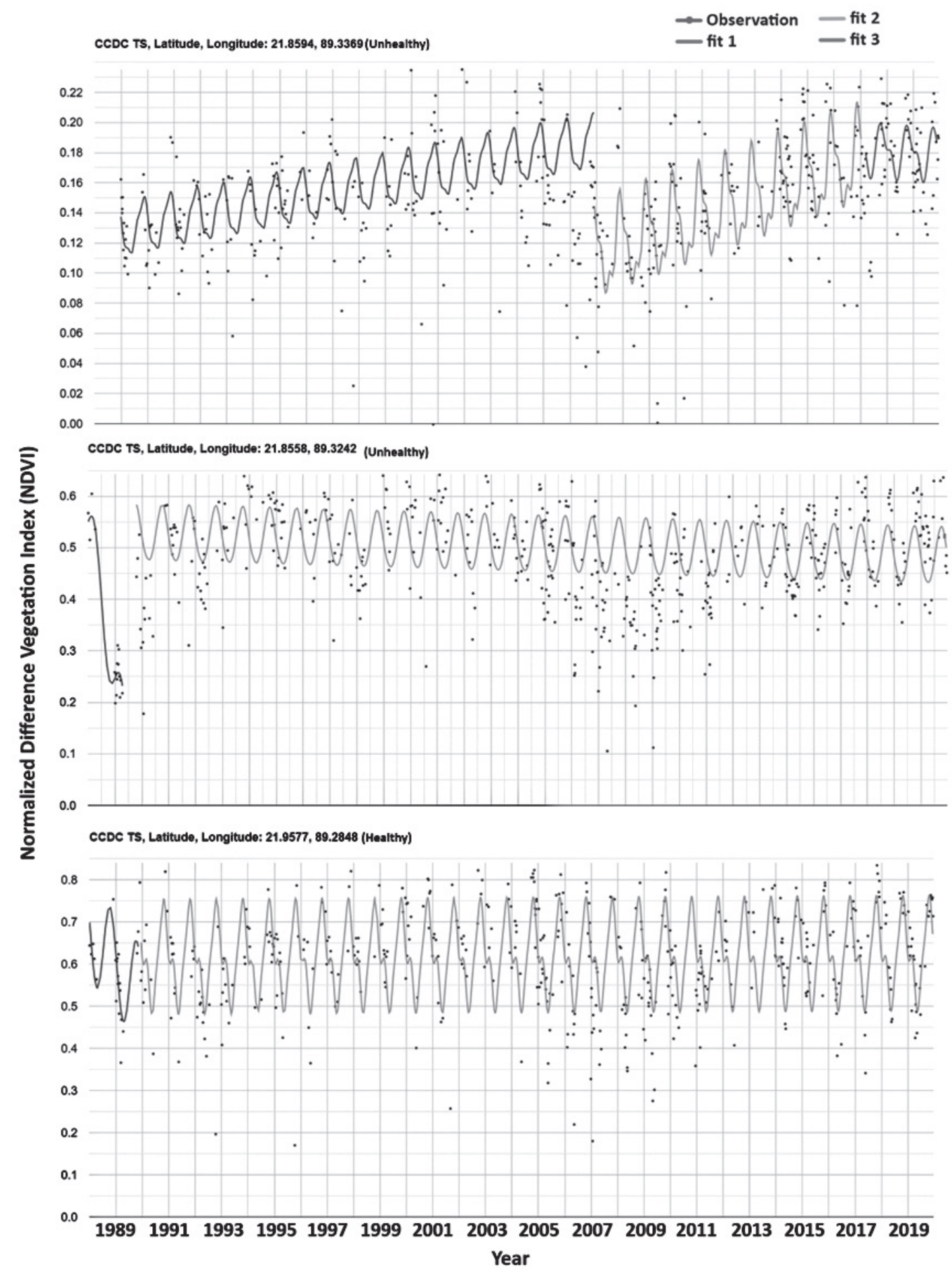

Fig. 6. The trend of forest cover (healthy and unhealthy) over the period using the CCDC algorithm 
The increase of water bodies $(1.30 \%)$ and subsequent decrease in vegetation cover in the Eastern Sundarban of Bangladesh was also reported by Kumar et al. (2021). The increase of water bodies indicates the climate changeinduced sea-level rise that is progressed slowly in the study area. The incessant sea-level rise is now a reality and it was projected that the sea-level rise may cause inundation of almost one-third of the low-lying coastal region of the Bengal delta as a consequence of about $2-5^{\circ} \mathrm{C}$ increase in temperature, and more that $10.0 \%$ increase in rainfall by 2100 (Pitchaikani et al., 2017). Already, rise in sea level, intrusion of salinity, frequent occurrences of the cyclone, uneven distribution of rainfall, and the temperature were the causes of reducing healthy vegetation. Sundarban, the world's most extensive continuous mangrove forests, are particularly critical and highly fragile to climate change effects because of its complex geographical setting and gradual decreasing under the rising sea (Lara et al., 2011).

Both healthy and unhealthy vegetation decreased at 1.33 and $1.66 \%$, respectively, from 1991 to 2021, but the degree of decrease was higher in unhealthy vegetation (Table 5). Mondal and Debnath (2017) estimated a $4.01 \%$ decrease of Sundarbans forest during the 19732010 periods. In this study, less estimation of degraded vegetation indicates that Sundarbans mangrove forest is now comparatively more stable than earlier. The principal causes of spatiotemporal changes of Sundarbans mangrove forests are deforestation, coastal accretion, and erosion (Islam et al., 2019). However, Hati et al. (2020) observed poor vegetation health due to increased stress in the entire mangrove forest of Lothian Island. The present study reports that such changes were inconsistent over three decadal estimations. The healthy vegetation consistently decreased at different rates over the decades, but unhealthy vegetation decreased during the 2001-2011 period. The conversion of healthy vegetation to healthy vegetation and vise versa during the 1991-2001 period was almost identical. However, during 2001-2011, such conversion was much higher from unhealthy to healthy vegetation. The transform of healthy vegetation to unhealthy vegetation was remarkably higher during the 2011-2021 period. The decrease of unhealthy vegetation and subsequent increase of healthy vegetation during 2001-2011 can the explained by the fact that cyclone Sidr extensively damaged mangrove forest in 2007 and rapid regrowth of mangrove occurred from 2007 to 2011 and possibly estimated higher healthy vegetation in 2011. Hussain and Islam (2020) also documented a low-density mangrove area due to cyclone Sidr but observed a high-density mangrove area in 2009.

\section{Conclusion}

The study reveals that the Sundarban earmarked forest in Bangladesh had not significantly altered from 1991 to 2021, and it is now stable. However, a temporal variation in areas under different land use classes was recorded. A consistent increase in water bodies but an inconsistent increase or decrease in healthy or unhealthy vegetation are observed in different decadal periods. The storms and cyclones may affect Sundarbans mangrove forest, but a quick regeneration of vegetative growth of the forest occurs that maintained the stability of the mangrove. The study 
quantified only the distribution and acreage of the healthy forest but not the species level. So, it can not suggest the status of species loss or shift, which is also vital for the sustainable existence of mangrove forests.

\section{References}

Abdullah, A. Y. M., A. Masrur, M. S. G. Adnan, M. A. Al-Baky, Q. K. Hassan and A. Dewan. 2019. Spatio-temporal patterns of land use/land cover change in the heterogeneous coastal region of Bangladesh between 1990 and 2017. Remote Sens. 11: 790.

Abdullah, H. M., I. Islam, M. G. Miah and Z. Ahmed. 2019. Quantifying the spatiotemporal patterns of forest degradation in a fragmented, rapidly urbanizing landscape: a case study of Gazipur, Bangladesh. Remote Sens. Appl: Soc. Environ. 13: 457-465.

Abdullah, H. M., M. G. Mahboob, M. M. Rahman and T. Ahmed. 2015. Monitoring natural Sal forest cover in Modhupur, Bangladesh using temporal Landsat imagery during 1972-2015. Int. J. Environ. 5(1): 1-7.

Alongi, D. M. 2008. Mangrove forests: resilience, protection from tsunamis, and responses to global climate change. Estuar. Coast. Shelf Sci. 76(1): 1-13.

Bangladesh Bureau of Statistics (BBS). 2018. Statistical Year Book of Bangladesh. Bangladesh Bureau of Statistics, Ministry of Planning, Peoples Republic of Bangladesh. P. 13.

Barik, J., A. Mukhopadhyay, T. Ghosh, S. K. Mukhopadhyay, S. M. Chowdhury and S. Hazra. 2018. Mangrove species distribution and water salinity: an indicator species approach to Sundarban. J. Coast. Conserv. 22(2): 361-368.
Chakma, S., A. K. Paul, M. A. Rahman, M. H. Mithun, and A. R. Sunny. 2021. Impact of climate change and ongoing adaptation measures in the Bangladesh Sundarbans.

Chakraborty, S., S. K. Saha and S. A. Selim. 2020. Recreational services in tourism dominated coastal ecosystems: Bringing the non-economic values into focus. $J$. Outdoor Recreat. Tour. 30: 100279.

Donato, D. C., J. B. Kauffman, D. Murdiyarso, S. Kurnianto, M. Stidham., and M. Kanninen. 2011. Mangroves among the most carbon-rich forests in the tropics. Nat. Geosci. 4(5): 293-297.

FAO. 2020. Global forest resources assessment 2020 - Main report.Rome

Feka, N. Z. and G. N. Ajonina. 2011. Drivers causing the decline of mangrove in WestCentral Africa: a review. Int. J. Biodivers. Sci. Ecosys. Serv. Manag. 7(3): 217-230.

Feller, I. C., D. A. Friess, K. W. Krauss and R. R. Lewis. 2017. The state of the world's mangroves in the 21 st century under climate change. Hydrobiol. 803(1): 1-12.

Giri, C., B. Pengra, Z. Zhu, A. Singh and L. L. Tieszen. 2007. Monitoring mangrove forest dynamics of the Sundarbans in Bangladesh and India using multitemporal satellite data from 1973 to 2000. Estuar. Coast. Shelf Sci. 73(1-2): 91-100.

Giri, C., E. Ochieng, L. L. Tieszen, Z. Zhu, A. Singh, T. Loveland and N. Duke. 2011. Status and distribution of mangrove forests of the world using earth observation satellite data. Glob. Ecol. Biogeogr. 20(1): 154-159.

Giri, C., E. Ochieng, L. L. Tieszen, Z. Zhu, A. Singh, T. Loveland, J. Masek and N. Duke. 2011b. Status and distribution of mangrove forests of the world using earth observation satellite data. Global Ecol. Biogeogr. 20: 154e159. 
Giri, C., J. Long, S. Abbas, R. M. Murali, F. M. Qamer, B. Pengra and D. Thau. 2015. Distribution and dynamics of mangrove forests of South Asia. J. Environ. Manage. 148: 101-111.

Gopal, B. and M. Chauhan. 2006. Biodiversity and its conservation in the Sundarban mangrove ecosystem. Aquatic Sci. 68(3): 338-354.

Hamilton, S. 2013. Assessing the role of commercial aquaculture in displacing mangrove forests. Bull. Mar. Sci. 89(2): 585-601.

Hasan, M. E., B. Nath, A. H. M. Sarker, Z. Wang, L. Zhang, X. Yang and M. Suza. 2020. Applying multi-temporal Landsat satellite data and Markov-cellular automata to predict forest cover change and forest degradation of Sundarban reserve forest, Bangladesh. Forests. 11(9): 1016.

Hati, J. P., S. Goswami, S. Samanta, N. Pramanick, S. D. Majumdar, N. R. Chaube and S. Hazra. 2020. Estimation of vegetation stress in the mangrove forest using AVIRIS-NG airborne hyperspectral data. Model. Earth. Syst. Environ. 1-13.

Hossain, M. I., M. R. Nabi, M. N. A. Ansari, A. Latif, M. R. Mahmud and M. S. Islam. 2016. Ecosystem services of the world's largest mangrove forest Sundarban in Bangladesh. Int. J. Innov. Sci. Res. 27(1): 9-15.

Hussain, N. and M. N. Islam. 2020. Hot spot model for forest vulnerability assessment: a remote sensing-based geostatistical investigation of the Sundarbans mangrove forest, Bangladesh. Model. Earth. Syst. Environ. 6: 2141-2151.

Iqbal, M. H. 2020. Valuing ecosystem services of Sundarbans mangrove forest: Approach of the choice experiment. Global Ecol. Conserv. 24: e01273.
Islam, M. M. and M. M. Hossain. 2017. Community dependency on the ecosystem services from the Sundarbans mangrove wetland in Bangladesh. In: Wetland Science. Springer, New Delhi, 301-316.

Islam, M. M., H. Borgqvist and L. Kumar. 2019. Monitoring mangrove forest landcover changes in the coastline of Bangladesh from 1976 to 2015. Geocarto. Int. 34(13): 1458-1476.

Islam, M. S. and M. A. Wahab. 2005. A review on the present status and management of mangrove wetland habitat resources in Bangladesh with emphasis on mangrove fisheries and aquaculture. Aquatic Biodivers. II: 165-190.

Islam, S. D. U. and M. A. H. Bhuiyan. 2018. Sundarbans mangrove forest of Bangladesh: causes of degradation and sustainable management options. Environ. Sustain. 1(2): 113-131.

Keenan, R. J., G. A. Reams, F. Achard, J. V. de Freitas, A. Grainger and E. Lindquist. 2015. Dynamics of global forest area: Results from the FAO Global Forest Resources Assessment 2015. Forest Ecol. Manag. 352: 9-20.

Kibria, A. S., R. Costanza, C. Groves and A. M. Behie. 2018. The interactions between livelihood capitals and access of local communities to the forest provisioning services of the Sundarbans Mangrove Forest, Bangladesh. Ecosyst. Services. 32: 41-49.

Kuenzer, C., A. Bluemel, S. Gebhardt, T. V. Quoc and S. Dech. 2011. Remote sensing of mangrove ecosystems: A review. Remote Sen. 3: 878-928.

Kumar, M., I. Mondal, and Q. B. Pham. 2021. Monitoring forest landcover changes in the Eastern Sundarban of Bangladesh from 1989 to 2019. Acta Geophys. 1-17. 
Lara, R. J., S. B. Neogi, M. S. Islam, Z. H. Mahmud, S. Islam, D. Paul, B. B. Demoz, S. Yamasaki, G. B. Nair and G. Kattner. 2011. Vibrio cholerae in waters of the Sunderban mangrove: relationship with biogeochemical parameters and chitin in seston size fractions. Wetl. Ecol. Manage. 19: 109-119.

Lundbäck, M., H. Persson, C. Häggström and T. Nordfjell. 2021. Global analysis of the slope of forest land. Forestry: Internat. J. Forest Res. 94(1): 54-69.

Minar, M. H., M. B. Hossain and M. D. Shamsuddin. 2013. Climate change and coastal zone of Bangladesh: vulnerability, resilience, and adaptability. Middle-East J. Sci. Res. 13(1): 114-120.

Mondal, S. H. and P. Debnath. 2017. Spatial and temporal changes of Sundarbans reserve forest in Bangladesh. Environ. Nat. Resour. J. 15(1): 51-61.

Morales-Hidalgo, D., S. N. Oswalt and E. Somanathan. 2015. Status and trends in global primary forest, protected areas, and areas designated for the conservation of biodiversity from the Global Forest Resources Assessment 2015. Forest Ecol. Manag. 352: 68-77.

Mozumder, M. M. H., M. M. Shamsuzzaman, M. Rashed-Un-Nabi and E. Karim. 2018. Social-ecological dynamics of the smallscale fisheries in Sundarban Mangrove Forest, Bangladesh. Aqua. Fisher. 3(1): 38-49.

Palacios, M. L. and J. R. Cantera. 2017. Mangrove timber is used as an ecosystem service in the Colombian Pacific. Hydrobiol. 803(1): 345-358.

Pitchaikani, J. S., K. S. Sarma and S. Bhattacharyya. 2017. First time report on the weather patterns over the Sundarbans mangrove forest, east coast of India. Indian J. GeoMar Sci. 46(4): 766-770.
Rahman, L. M. 2016. Development initiatives of the Sundarban of Bangladesh. Malaysian Forester. 79 (1\&2): 77-88.

Rahman, M. M., Y. Jiang and K. Irvine. 2018. Assessing wetland services for improved development decision-making: a case study of mangroves in coastal Bangladesh. Well. Ecol. Manag. 26(4): 563-580.

Rahman, M. U., A. Majumder, J. Chakrabarti and A. Sarkar. 2015. Prospects of tourism entrepreneurship in West Bengal: A Study with special reference to Sunderbans.

Rasquinha, D. N. and D. R. Mishra. 2021. Impact of wood harvesting on mangrove forest structure, composition, and biomass dynamics in India. Estuar. Coast. Shelf Sci. 248: 10697

Romañach, S. S., D. L. DeAngelis, H. L. Koh, Y. Li, S. Y. Teh, R. S. R. Barizan and L. Zhai. 2018. Conservation and restoration of mangroves: Global status, perspectives, and prognosis. Ocean Coast. Manage. 154: 72-82.

Sahu, S. C., H. S. Suresh, I. K. Murthy and N. H. Ravindranath. 2015. Mangrove area assessment in India: implications of the loss of mangroves. J. Earth Sci. Clim. Change. 6(5):1.

Sannigrahi, S., S. Chakraborti, P. K. Joshi, S. Keesstra, S. Sen, S. K. Paul and K. B. Dang. 2019. Ecosystem service value assessment of a natural reserve region for strengthening protection and conservation. J. Environ. Manage. 244: 208-227.

Shah, M. A. R. and D. K. Datta. 2010. A quantitative analysis of mangrove forest resource utilization by the dependent livelihoods. ISEE Conference on Advancing Sustainability in a Time of Crisis, August 22-25, Oldenburg-Bremen, Germany. 
Uddin, M. S., E. D. R. van Steveninck, M. Stuip and M. A. R. Shah. 2013. Economic valuation of provisioning and cultural services of a protected mangrove ecosystem: a case study on Sundarbans Reserve Forest, Bangladesh. Ecosyst. Serv. 5: 88-93.

Uddin, M. S., M. A. R. Shah, S. Khanom and M. K. Nesha. 2013. Climate change impacts on the Sundarbans mangrove ecosystem services and dependent livelihoods in Bangladesh. Asian J. Conserv. Biol. 2(2): 152-156.

Vyas, P. and K. Sengupta. 2012. Mangrove conservation and restoration in the Indian Sundarbans. Sharing Lessons on Mangrove Restoration. 93. 